UDC 39

\title{
FORMATION OF ETHNIC VALUES OF PERSONALITY IN THE CONTEXT OF ETHNIC EDUCATION
}

\author{
(c) Marina V. Makhrinova, Igor P. Makeenko, Olga V. Kashirina
North-Caucasus Federal University, Technological Institute of Service (affiliated to DSTU), Stavropol, Russian Federation
mmakhrinova@ncfu.ru

Ethnic upbringing is a purposeful interaction of generations, as a result of which ethnic selfconsciousness is formed that is adequate to treat oneself as a subject of an ethnic group, a sense of pride in their ethnic group, a positive attitude to the language, history, culture of their ethnic group, as well as a sense of respect and tolerance for representatives of others ethnic groups. The essence of ethnic education is the preservation, formation and development of the ethnic identity of the individual, his culture, self-identity, language based on the continuity of generations, taking into account the changing conditions. As a content and means of ethnic education, the development of ethnosocial roles is considered, the formation of which is the mastery of this role in accordance with age. To preserve their identity, integrity, independence, individual freedom, you first need to understand your ethnic upbringing. This is the first step and at the same time the main thread of life, it is not discrete, it is continuous, it starts from the moment of conception of a child and continues throughout life. However, at the same time, ethnic education is a deeply specific upbringing, it must penetrate the whole spirit of the family, the general educational institution, especially the initial link, and then, really, on the basis of the native, the education of a multicultural personality should be carried out. The ultimate goal of ethnic education is the upbringing of an ethnocultural personality, identifying himself with his own ethnos, which perceives the world through the prism of its national-specific features.

Key words: individual, personality, education, socialization, public relations, cultural and historical experience, culture of ethnos, ethnic culture, ethnocultural values, ethnocultural education.

\section{[М.В. Махринова, И.П Макеенко, О.В. Каширина Формирование этнических ценностей личности в контексте этнического воспитания]}

Этническое воспитание - это целенаправленное взаимодействие поколений, в результате которого формируется этническое самосознание, адекватное отношению к себе как к субъекту этноса, чувство гордости за свой этнос, положительное отношение к языку, истории, культуре своего этноса, а также чувство уважения и толерантности к представителям других этносов. Сущность этнического воспитания заключается в сохранении, формировании и развитии этнической самобытности личности, ее культуры, самосознания, языка на основе преемственности поколений с учетом изменившихся условий. Как содержание и средство этнического воспитания рассматривается освоение этносоциальных ролей, показателем сформированности которых является овладение этой ролью в соответствии с возрастом. Чтобы сохранить свою самобытность, целостность, независимость, свободу личности, сначала надо понять свое этническое воспитание. Это первая ступень и в то же время основная нить жизни, оно не дискретно, оно беспрерывно, оно начинается с момента зачатия ребенка и продолжается в течение всей жизни. Но в то же время этническое воспитание - глубоко специфическое воспитание, им должны быть проникнуты весь дух семьи, общеобразовательное учреждение, особенно начальное звено, а дальше, действительно, на основе родного должно осуществляться воспитание поликультурной личности. Конечной целью этнического воспитания является воспитание этнокультурной личности, идентифицирующей себя со своим этносом, который воспринимает мир сквозь призму своих национально-специфических особенностей.

Ключевые слова: индивид, личность, воспитание, социализация, общественные отношения, культурно-исторический опыт, культура этноса, этническая культура, этнокультурные ценности, этнокультурное образование. 
Marina V. Makhrinova - Ph.D. in Pedagogy, Associate Professor, North-Caucasus Federal University, Stavropol, Russian Federation.

Igor P. Makeenko - Ph.D. in Economy, Associate Professor, Technological Institute of Service (affiliated to DSTU), Stavropol, Russian Federation.

Olga V. Kashirina - Ph.D. (Advanced Doctorate) in Philosophy, Associate Professor, North-Caucasus Federal University, Stavropol, Russian Federation.

Махринова Марина Владимировна - кандидат педагогических наук, доцент, Северо-Кавказский федеральный университет, г. Ставрополь, Российская Федерация.

Макеенко Игорь Петрович - кандидат экономических наук, доцент, Технологический институт сервиса (филиал) ДГТУ в г. Ставрополе, Российская Федерация.

Каширина Ольга Валерьевна - доктор фрилософькких наук, доцент, Северо-Кавказский федеральный университет, е. Ставрополь, Российская Федерация.

The process of ethnic education is the organic, permanent development of a representative of an ethnic group throughout a lifetime. The result of ethnic education is the assimilation of ethnic values, the use of ethnosocial roles, ethnic norms embedded in the traditions of one or another ethnic group.

The value approach is very important. Thanks to such features of education as continuity, variability and inertness, it is possible to transfer the basic values in education from one generation to another, taking into account the changed socio-political, socio-economic conditions. An essential feature of culture is the presence in it of traditional, historically developed by the people and selected ideas - values. Each culture differs from the other in an exclusive set of values that determine the specific behavior of its representatives.

The idea of value is formed due to the coverage of a wide range of phenomena of the spiritual and material world, which are the foundation for the individual and are an indispensable condition for the formation of personality. A person accepts the values of one or another group as attitudes that determine his behavior, and does not choose as separate value orientations. An individual cannot influence the value itself; however, it implements them, makes attempts to follow these value principles.

As M.S. Kagan notes, recognition of the priority of truth in the system of values, scientific awareness of the experience of mankind, and specifically the correlation of the world of scientific rationality and the axiological world, creates the opportunity to revive harmonious relations based on the principle of complementarity.

G.P. Vyzhletsov in his writings notes that the functioning and manifestation of values in society is determined by the relationships arising between the subject and the object. On the one hand, various objects, their properties of a phenomenon, can be a value, and on the other hand, judgments related to the assessment of specific objects, phenomena and society as a whole. The mediating links connecting society and the individual are the system of values and the way of life of a person. They act as key mechanisms for the inclusion of man in global social relations. In order for a person to realize the importance of value, he/she must have a guide in some groups of values. At the stage of awareness by a specific individual of the value of social reality, a special type of relationship in society is formed - a value relationship. The orientation method in the system of values acts as an internal psychological mechanism that forms various preferences of a person according to the nature of purposefulness, which determines the specificity of its value relations.

According to $\mathrm{M}$. Rokich, value is treated as a transcendental recipe, positive or negative, not associated with a specific situation or with a specific object, expressing a person's beliefs about patterns of behavior or primary goals. Values are part of the worldviews of various ethnic groups, and act as a way of reaction of these groups to certain situations. In dif- 
ferent societies, values differ from each other, due to the fact that they act as a product of socialization in a particular culture. In his study, M. Rokich identifies the main characteristics of values. Thus, he noted that values stand out as stable facts of consciousness, and there are values that act as group beliefs or as individual beliefs. To support self-esteem and selfrespect, values are declared as the main means of human consciousness and selfawareness. They define "... the quality of a person and the ability of social subjects to deliberately interact with the environment" [6, p. 282-284], "the complex interaction of various types of social communication" [1, p. 5-10].

L.S. Vygotsky established that the process of socialization and the formation of personality is accomplished thanks to the development by the individual of the value system of a certain cultural and historical community, cultural and historical experience, but without the influence of some a priori reality. These norms are fixed in the traditions of ethnocultural community or religious culture. They can act as a model, which is the quintessence of the value system adopted in this society. Acquaintance with culture is due to the development of images, as social experience is transmitted and fixed in the form of formed cultural objects.

The core of culture consists of universal human goals and values, as well as historically established ways of their perception and achievement. But, speaking as a universal phenomenon, culture is perceived, mastered and reproduced by each person individually, conditioning its formation as a person.

Heredity predetermines the genetic reproduction of generations, and the ontogenesis of spiritual life of both man and society is based on the ongoing process of transmission from generation to generation of experience and knowledge materialized through spiritual values. Without a deep understanding of the ethnos culture, it is impossible to understand its spiritual and moral values. A person acts in the coordinates of national and universal values. The cultural heritage reflects the values of various civilizations; it acts as an integral part and an indispensable condition for the development of society, both its socio-economic component and the spiritual component.

The process of adaptation to the value system contributes to the formation and formation of a personal (ethnic) value system. Even the ideal values of humanity must undergo a process of rebirth in empirical experience, for their appropriate appropriation in the future, in order to get a personal semantic coloring. In all historical epochs, man, in particular, and all people in general, act as carriers of historical values.

The value cannot be forced to accept or take away, it cannot be purchased or sold for money, it cannot be presented or received as a gift as a present. It is impossible to simply become familiar with the value, to join; value must be created by yourself, or rather to create it in yourself and each time to revive again in any value situation, going through various difficulties.

A person oriented to a system of universal values through ethnoculture can be regarded as a phenomenon combining various facets of a person's value assimilation of reality, the subject's metamorphosis in action and in the process of the formation of this person's culture.

The study of differences in cultural values, which was conducted by G. Hofstede, notes the disclosure of the nature of cultural differences, which is the result of differences in the judiciousness of people. Cultural differences are revealed in the essential manifestations of culture, these are symbols, heroes, traditions, and, in particular, values. The system of symbols acts as a superficial manifestation of culture, and the system of values already acts as a thorough, fundamental expression of culture.

Each ethnic culture includes a combination of values of all areas of material and spiritual life. Orientation of an individual to a system of universal values through ethnic culture can be interpreted as a phenomenon that integrates the main facets of the value development of reality by an individual, his socialization through practical activities and the formation of his culture. 
Ethnic culture is a means of educating and improving the individual, mastering the values of the surrounding social and natural world. This is a key condition for the formation of harmonious relations with the surrounding reality, as well as with oneself through the appropriation of social and historical experience. Experience, in turn, is recorded in the form of historically established elements of culture, embodied in value orientations selected by the ethnic group and mastered in activities. These values, passing through the individual vital activity of the personality, are part of the psychological structure of the personality in the form of personal values. They are designated as a source of motivation for individual behavior and the relationship of the individual to the surrounding reality. Values of a personal nature, this is the part that connects the culture of society and the spiritual world of a person, connects social and individual being.

The most important essential value of a person is recognized as its social significance as a fundamental universal human value and invariant. On the basis of the ethnocultural system of values functioning in society, a specific set of signs of understanding reality, one's place in this world is formed.

The personality - the subject of ethnic culture - is not only its consumer, but also the bearer and creator of cultural values, determines in its development the qualitative characteristics of the reproduction of ethnic experience. Personality is the result of the distribution of ethnocultural values: language, traditions, methods of activity and thinking - and forms itself in the process of activity as an ethno-cultural-historical being. Ethnicity or individual individuals, mechanically borrowing other spiritual values, types of thinking, lose their ability to create within their native and other cultures.

The complex and controversial process of the formation and development of culture is inseparable from taking into account the laws of phylogenesis and ontogenesis. In the past, each newborn forced a certain structure of values that did not change for centuries, regulating the orientations of many generations.

Ethnic identity of a person consists, first of all, in a unique combination of elements common to all ethnic groups, in a combination of a system of relations and values. Therefore, with the change of ideas, currents, they evolve: some disappear, others appear, some rise, others fall; a new ideological system predetermines a new hierarchy of values. Some values express the hopes and aspirations of an ethnic group: freedom, equality, happiness, homeland, family, work; people live with other values: pessimism, honor, tolerance, politeness, respect for others. On the basis of the ethnocultural system of values functioning in society, a specific set of signs of understanding reality, one's place in this world is formed in a person.

Ethnic culture and education are two components of the process of formation and development of the individual through the assimilation of the cultural value system. Ethnic culture is analyzed from the perspective of the process and the result of transformational activity; it is both the goal and the content of education. The system of values based on ideals is transformed for the goals and objectives of the education system and acts as a key link in the analysis of the phenomena of pedagogy. They are reflected in the educational process and provide an opportunity to consider its nature and essence. Values of ethnocultural nature allow us to see its directional vector. Each historical stage in the development of society encourages the educational system to seek a new system of values that will concentrate around the humanistically oriented ideal of education.

As a general principle in the field of education, a continuous process of transmission from generation to generation of spiritual values, ethnocultural traditions and features that reflect various aspects of life support, which are a manifestation of ethnocultural memory, form new ethnos value orientations, is approved.

The system of ethnocultural education turns human values into concrete recognizable ethno-cultural heritage. Categories, knowledge of a general ethnic character play the role of permanent value and, as a result, become the heritage of every person. Such a process al- 
lows for the development of a sense of self-confidence and abilities in the educated, revives ethnic self-awareness, develops self-awareness, and develops responsibility for the preservation and development of ethnic traditions and the desire to maintain a healthy lifestyle.

Ethnic culture contributes to the self-identification of a person with a particular ethnic group; it contributes to the emergence of a desire to work for the good of their ethnic group. It helps the formation and development of the pedagogical way of thinking of an ethnic group. All of the above allows us to note that the orientation of the educational system towards ethnic culture is an integrative phenomenon, on which the processes of deepening, expanding and accepting at the personal level a system of universal human values.

The nature of the emergence of the value system lies in the sphere of formation and satisfaction of human needs i.e. the driving force, source and causes of its activity. Value is the subject of human needs - things or ideas. A need is initially designated as a prerequisite, however, when human activity begins, it also begins to transform. The prerequisite for achieving results is the premise. This need is focused on the future; it is the need that creates the standards of life for the future. A need urges a person to overcome the environment of his being, creating new forms of life. The main purpose of the exaltation of needs is to enable the individual to realize the importance of a particular value and to make the right choice in a certain situation through awareness and acceptance of universal and national values. The environment is an effective means of satisfying human needs. Ethnic culture does not contain superfluous and useless, it is an instrumental mechanism thanks to which a person better copes with extraordinary difficulties in the process of satisfying his needs, and difficulties, in turn, are due to the human environment. The formation and satisfaction of needs is the driving force, source, process of resolving contradictions and the reason for the activity of a person, thanks to which his personality structures are formed and changed. The main purpose of the selection of a particular need and its elevation is a person's awareness of the importance of value and experiencing it in a situation of choosing a value reference point through an ascent to universal values and ethnocultural values.

The reproduction of ethnoculture is an entry into the world of universal values through the development of personalism in the bosom of native culture, the satisfaction of the needs of ethnocultural expression and self-realization. The development of the personality does not occur under the influence of any influences, but mainly those that express the needs of the person, are addressed to his personality, and are based on his own attitude to reality.

The subjects of educational systems starts to understand the need to more actively saturate the educational process with ethnocultural components by means of developing and educating the person, mastering the values of the surrounding ethno-social environment, the conditions for harmonizing relations with the outside world and oneself through the appropriation of socio-historical experience, fixed in historical form prevailing cultural objects embodied in ethno-selected spiritual and moral ideas-values and mastered in activities that promote dialogue of cultures in the context of the development of modern culture [7].

Orientation to certain values makes up value orientations (the result of people's free choice) that characterize the orientation of the person, expressed in the awareness and experience of the values and needs of society, which motivate real behavior and program the future. A qualitative leap becomes possible not when new ideas arise, but when new value orientations mature. The value orientations of the personality in its general structure play the role of a strategic line of behavior, the function of an integrator of various forms of human activity, out of many social roles, attitudes, value orientations of a person, only a few enter the personality structure, which, as the highest value, is based on a real presence in the human mind [8]. Value orientation is the material on the basis of which one or another ethnic culture crystallizes.

The system of value orientations changes depending on the historical period of the development of society, which naturally changes in historical time [3, pp. 45-49], is closely con- 
nected with historical memory [10, pp. 41-47]. Ethnicity can take any value orientation depending on historical fate, cultural tradition and external environment. Therefore, every individual person can theoretically accept any values, although in practice their choice is largely determined by the nature of his upbringing and education, as well as his life experience. This choice is not genetically determined for humans. Both for an individual person and for an ethnos, the role of the external environment in the choice of value orientation is huge.

For the normal functioning of society, a reproducible and constantly updated system of value orientations is needed. The value orientation sets the goal (rebirth of the people, the ideal image of a perfect personality), includes an arsenal of means of action (which should, is allowed), gives an idea of good and evil, the image of the world (including cosmological, sociological, cultural and anthropological components), research ideas about history and politics passed down from generation to generation, about which events are the most significant, factors, the most significant, situations and the most typical.

The formation of value orientations reflects the process of the formation of the personality, and the value orientation itself represents a set of socially significant values in their individual and personal manifestation. The value orientations of ethnoculture provide a systematic, integrity-forming personality. The system of value orientations of the individual for a long time developed under the influence of religion, which took the role of social morality, the decisive factor, and the most important component of ethnocultural identity. The formation of value orientations is based on the activity aspect of needs.

Culture as a system of subjective meanings and value orientations and at the same time as a spiritual potential determines the vector and boundaries of the behavior of subjects in society, provides a positive attitude to cultural differences [2]. "Culture is understood as the inner essence of human ideas ..." [9, pp. 3-9]. Value orientation is the material on the basis of which this or that ethnic culture crystallizes. Values, value orientations are mobile in relation to society, history, and the individual person. The choice of a value orientation by an ethnos is made by the bearers of the personality type of consciousness associated with "public consciousness ... general cultural norms and values" [6, pp. 6-12].

For the normal functioning of an ethnic group, a reproducible and constantly updated system of value orientations that correct the educational system is needed, which at this stage set the goal - the revival of peoples, in accordance with which the educational system should be adjusted. The problems of the revival of spirituality, the development of a humanistic worldview and value orientations of the individual, their inclusion in ethnocultural experience are becoming urgent, they require updating the content of education, substantiating new worldview ideas, concepts, categories of their personal perception by students and providing real opportunities for a humanistic worldview of a person focused on historical and ethnocultural values of the people, to affirm the ideals of humanism in the consciousness and behavior of students.

Ethnocultural sources contain the program-oriented goals in the field of education that prevail in this community in a given historical period, which give the ethnos a real opportunity to determine current ethnocultural value priorities. It is important to analyze historical texts, which are the quintessence of the value system, texts that are not translated but written by the hand of the bearer of this ethnic culture, reflecting the value dominants that form the ideology of the development of the ethnic group. The value orientation is also given to its own ideal image, and it partly includes the arsenal of means of action (what should and what is allowed). She also sets a meaningful idea of good and evil, gives some schematic image of the world (including cosmological, sociological, cultural and anthropological components). Ideology defines an algorithm of action, and therefore people consider themselves capable of this action. The popular notions of history and politics are investigated. There is a special political folklore, that is, ideas passed down from generation to generation about which events 
in history and politics are most significant, which factors are most significant, and which situations are most typical.

P.F. Kapterev related features of the pedagogical process, due to national values, attributed language, religion, life. He regarded the acquisition of his native language as an introduction to national spiritual values and, at the same time, to universal human knowledge, forming scientific views on the world around him, called for the development in children of a sense of belonging to all of humanity. Pedagogical activity is first carried out on the basis of the national ideal, and then is transformed into activity to achieve the universal ideal. In upbringing, it is necessary to appeal not to one people, but to many, to consider their ideals and to fill up the shortcomings of their national ideal with valuable foreign properties; folk should be combined with a foreign, with a national and universal.

Education is impossible without appeal to the individual. Personality as a cultural phenomenon has always been included in the prestigious goals of education or has been declared as such. Nevertheless, usually a person was a means, not a goal of education. The child's personal potential has been activated to achieve an external goal. Education focused on personality development is a special type of education that is more complex in terms of organizational and structural characteristics and psychological mechanisms. Its goal is to develop in a child the ability to be a person: choose life's meanings and principles, make decisions, be responsible for his words and actions, be independent, internally free, proactive and creative, to control himself. The fulfillment of these special kinds of actions on the internal self-organization of the individual consists in the purpose of the personality, its function. These functions essentially constitute the moral core of the personality, the potential of its civic development, socialization, one way or another determine the socio-cultural development of society [4, pp. 123-128].

\section{Лumepamypa}

1. Бакланова О.А., Бакланов И.С. Контуры типологического исследования социальности современного общества // Известия Саратовского университета. Новая серия. Серия: Философия. Психология. Педагогика. 2014. Т. 14. № 2-1. С. 5-10.

2. Власова В.Н. Региональное социокультурное пространство дополнительного профессионально-педагогического образования / автореферат диссертации на соискание ученой степени доктора философских наук. Ростов-на-Дону, 2010.

3. Гончаров В.Н. Социальный аспект религии в контексте развития первобытного общества // Гуманитарные и социально-экономические науки. 2016. №2(87). С. 45-49.

4. Ерохин А.М. Научно-информационный аспект исследования социокультурного развития общества в области культуры и искусства // Экономические и гуманитарные исследования регионов. 2015. № 2. С. 123-128.

5. Колосова О.Ю. Духовная сфера: универсализм и самобытность // European Social Science Journal. 2012. №11-2(27). C. 6-12.

6. Лобейко Ю.А. Социальная активность личности в обществе: социальнопедагогические аспекты фрормирования // European Social Science Journal. 2014. №7-2(46). С. 282-284.

7. Матяш Т.П., Несмеянов Е.Е. Проект модернизации - европейский соблазн // Вестник Волгоградского государственного университета. Серия 7: Философия. Социология и социальные технологии. 2011. № 2 (14). С. 57-61.

8. Мустафраева М.Г., Мустафраев М.В. Вопросы социально-психологического поведения личности: национальные и этноконфессиональные аспекты // Известия Северо-Кавказского научного центра высшей школы. Естественные науки. № 2. 1987. C. 95. 
9. Berkovskiy V., Tronina L. Social and historical aspect of interaction of ethnic culture and personality in the context of public development // Научный альманах стран Причерноморья. 2019. №1(17). С. 3-9.

10. Kuleshin M., Leonova N., Nemashkalov $P$. Historical consciousness as a part of national consciousness: to the problem statement of the research // Научный альманах стран Причерноморья. 2019. №1(17). С. 41-47.

\section{References}

1. Baklanova O.A., Baklanov I.S. Kontury tipologicheskogo issledovaniya sotsialnosti sovremennogo obshchestva. [The contours of a typological study of the sociality of modern society]. Izvestiya Saratovskogo universiteta. Novaya seriya. Seriya: Filosofiya. Psikhologiya. Pedagogika. 2014. V. 14. No. 2-1. pp. 5-10 (In Russian).

2. Vlasova V.N. Regionalnoye sotsiokulturnoye prostranstvo dopolnitelnogo professionalno-pedagogicheskogo obrazovaniya. Avtoreferat dissertatsii na soiskaniye uchenoy stepeni doktora filosofskikh nauk. [Regional socio-cultural space of additional professional and pedagogical education. Abstract of the dissertation for the degree of Doctor of Philosophy]. Rostov-on-Don. 2010 (In Russian).

3. Goncharov V.N. Sotsialnyy aspekt religii v kontekste razvitiya pervobytnogo obshchestva. Gumanitarnyye i sotsialno-ekonomicheskiye nauki. [The social aspect of religion in the context of the development of a primitive society. Humanitarian and socio-economic sciences]. 2016. No. 2(87). pp. 45-49 (In Russian).

4. Erokhin A.M. Nauchno-informatsionnyy aspekt issledovaniya sotsiokulturnogo razvitiya obshchestva $v$ oblasti kultury $\mathrm{i}$ iskusstv. Ekonomicheskiye i gumani-tarnyye issledovaniya regionov. [The scientific and informational aspect of the study of socio-cultural development of society in the field of culture and art. Economic and humanitarian studies of the regions]. 2015. No. 2. pp. 123-128 (In Russian).

5. Kolosova O.Yu. Dukhovnaya sfera: universalizm i samobytnost. European Social Science Journal. [Spiritual sphere: universalism and identity. European Social Science Journal]. Rostov-on-Don. 2013. pp. 170-174 (In Russian).

6. Lobeiko Yu.A. Sotsialnaya aktivnost lichnosti v obshchestve: sotsialnopedagogicheskiye aspekty formirovaniya. [Social activity of an individual in society: socio-pedagogical aspects of formation] European Social Science Journal. 2014. No. 7-2 (46). pp. 282-284 (In Russian).

7. Matyash T.P., Nesmeyanov E.E. Proyekt modernizatsii - yevropeyskiy soblazn. Vestnik Volgogradskogo gosudarstvennogo universiteta. Seriya 7: Filosofiya. Sotsiologiya i sotsialnyye tekhnologii. [Modernization project. European temptation. Bulletin of Volgograd State University. Series 7: Philosophy. Sociology and social technology]. 2011. No. 2 (14). pp. 57-61 (In Russian).

8. Mustafaeva M.G., Mustafaev M.V. Voprosy sotsialno-psikhologicheskogo povedeniya lichnosti: natsionalnyye i etnokonfessional'nyye aspekty. Izvestiya SeveroKavkazskogo nauchnogo tsentra vysshey shkoly. Yestestvennyye nauki. [Issues of socio-psychological personality behavior: national and ethno-confessional aspects. Bulletin of the North Caucasian Scientific Center of Higher Education. Natural Sciences]. No. 2. 1987.95 p. (In Russian). 
9. Berkovskiy V., Tronina L. Social and historical aspect of interaction of ethnic culture and personality in the context of public development. Science almanac of Black Sea region countries. 2019. No. 1 (17). pp. 3-9.

10. Kuleshin M., Leonova N., Nemashkalov P. Historical consciousness as a part of national consciousness: to the problem statement of the research. Science almanac of Black Sea region countries. 2019. No. 1(17). pp. 41-47. 